\title{
Legal Protection of Female Journalists over Gender Inequality during the Covid-19 Pandemic
}

\author{
Vena Lidya Khairunissa \\ Faculty of Law, Universitas Negeri Semarang, Semarang, Central Java, Indonesia \\ Email: venalidyak@gmail.com \\ ORCID Link: https://orcid.org/0000-0003-3210-6910 \\ Muhammad Ilham Nurrobby \\ Department of Industrial Management, Lunghwa University of Science and Technology, Taiwan
}

\section{Citation:}

Khairunissa, V. L. \& Nurrobby, M. I. (2021). Legal Protection of Female Journalists over Gender Inequality during the Covid-19 Pandemic. Lex Scientia Law Review, 5(2), 123-136, doi: https://doi.org/10.15294/lesrev.v $5 \mathrm{i} 2.50438$.

\section{History of Article}

Received: September 30, 2021

Revised: November 11, 2021

Accepted: November 19, 2021

(C) The Author(s)

\section{(c) (1) 8 (O)}

This work is licensed under a Creative Commons Attribution-NonCommercialShareAlike 4.0 International License. All writings published in this journal are personal views of the authors and do not represent the views of this journal and the author's affiliated institutions.

Lex Scientia Law Review published by Faculty of Law, Universitas Negeri Semarang, Indonesia in collaboration of UKM Lex Scientia. Published biannually every May and November.

\begin{abstract}
The purpose of this study was to find out the legal problems experienced by female journalists over gender inequality during the Covid-19 pandemic and to find out the legal protections to overcome these problems. The type of research used is a normative legal research type with an invitation approach and a historical approach. The findings in this paper are, during the Covid-19 pandemic, gender inequality towards female journalists has increased. It is still very rare for people to raise issues related to gender inequality experienced by female journalists. Examples of problems with a gender perspective in the media are the lack of involvement for women in journalism activities, marginalization and subordination positions for women in various fields, legitimacy regarding gender bias, dominating economic and political interests, regulations on media that are not sensitive to gender and between conventional journalism and gender. equality. The government in Indonesia officially adheres to the principle of equality as regulated in Article 27 of the 1945 Constitution of the Republic of Indonesia which states that all Indonesian citizens are equal before the law. Therefore, journalists must be able to enjoy gender and legal protection for the gender inequality they experience. It is necessary to reconstruct the law, considering that women have the same position as men in terms of their position, rights and obligations so
\end{abstract}




\section{that they have equal opportunities in various fields.}

\section{KEYWORDS}

Gender equality; Legal protection; Women Journalists

\section{INTRODUCTION}

Journalism is essential to the development of a country. History records an independent Indonesia does not escape the struggle of a journalist. Indonesian journalists act as press activists by carrying out news and lighting tasks to generate national awareness in the movement. Journalists also work as political activists by being directly involved in people's resistance activities against colonialism. In the era of movement until now, journalists must have balance in terms of helping to proclaim the development carried out by the government and at the same time become the objective control of the government.

Indonesia has guaranteed freedom of opinion to realize a democratic country and remain grounded in the law. This is stated in article 28 of the Constitution of the Republic of Indonesia of 1945. This article also accommodates the value of press freedom. Although the Act has guaranteed the release of the press, in reality, journalists have not been fully able to carry out their duties safely and calmly.

There are many risks that journalists must go through while serving in the field. Being a journalist is not easy, especially for female journalists. A woman who chooses to become a journalist must have high enough mental and physical strength, especially when faced with more powerful things. Journalists should always be prepared to be sent coverage to conflict areas, such as criminal cases, demonstrations, and even warfare. They were working as a journalist is high risk because life is a bet to get the truth.

Law No. 40 of 1999 concerning the Press, according to Hiru R. Muhammad, became a legal umbrella in providing legal protection for the journalistic profession and remained in its responsibility to provide information in the public interest. ${ }^{1}$ The establishment of the Press Council also aims for the interests of the press in seeking justice. However, on the other hand, a journalist must become a professional in carrying out their duties and be committed to improving their abilities. The professionalism of journalists means that digging up information that is then disseminated must be based on the rules and norms that apply to a journalist. As Hiru R. Muhammad said, freedom of the press must still have limits. Journalists must always be

1 Erman Anom, “Wajah Pers Indonesia 1999-2011," Jurnal Komunikasi: Malaysian Journal of Communication, Volume 27 Number 1, 2011, p. 101-114. 
responsible to the public and uphold professionalism so that the news published does not cause unrest and division.

Now the Covid-19 pandemic is a challenge for journalists in carrying out their duties. A lot of unexpected things can happen during the coverage. Getting to the location of the cover alone is already quite extraordinary.

Insecurity sometimes appears to Journalists because adequate selfprotection tools during coverage are not with them. The Covid-19 pandemic also caused many journalists to lose their jobs as the media cut costs to pay contributors. Not only that, but lawsuits against journalists during the Covid19 pandemic are also high with the label that they are spreading false information. That affects the mental health of journalists as well.

Ironically, in addition to fighting the impact of the Covid-19 pandemic, female journalists also continue to be haunted by patriarchal cultural heritage. Reporting from Okenews dated May 18, 2020, Ratna Ariyanti - Member of the Employment Section of the Alliance of Independent Journalists (AJI) Indonesia - revealed that the Covid-19 pandemic resulted in female journalists losing their jobs. It also said that they have difficulty finding data protection tools covering, and coupled with gender injustice that still exists. ${ }^{2}$

According to some feminists, a patriarchal society is one reason why discrimination still exists in the field of mass media. The goal is to maintain male dominance. ${ }^{3}$ The media is still considered to perpetuate stereotypes that harm women. In mass media, gender bias is described by displaying marginalized and subordinated female figures. Many people assume that the world of journalism only accommodates men. ${ }^{4}$ Not a few female journalists experience injustice and gender inequality due to regulations about women that only look at the sectors of biological nature, beliefs, and culture. Article 27 of the Constitution Republic Indonesia of 1945 has affirmed the position of Indonesian citizens in the eyes of the law is the same without discrimination from any parties.

The issue of sexual harassment experienced by female journalists in the workplace has also not shifted. Harassment can occur anywhere and anytime when journalists work, such as when interviewing sources and being invited

\footnotetext{
2 Pernita Hestin Untari, "Nasib Jurnalis di Tengah covid-19, Tuntutan Tinggi tapi Minim Perlindungan", Oke News, May 18 2020, accessed from https://nasional.okezone.com/read/2020/05/18/337/2215933/nasib-jurnalis-di-tengah-covid-19tuntutan-tinggi-tapi-minim-perlindungan?page $=2$.

${ }^{3}$ M. Hidajadi, "Hubungan Ibu dan Anak Perempuan: SebuahDistorsi?", Jurnal Perempuan: Untuk Pencerahan dan Kesetaraan, Number 16,2003, p. 7-15.

4 Yolanda Stellarosa dan Martha Warta Silaban, "Perempuan, media dan profesi jurnalis", Jurnal Kajian Komunikasi, Volume 7 Number 1, 2019, p. 97-109.
} 
to date to the police. Many mass media companies do not yet have specific policies and channels for complaints of discrimination and sexual harassment in journalists' workplaces. Generally, sexual harassment complaints are directed to superiors. That becomes difficult when the perpetrator of sexual violence is his superior. ${ }^{5}$

Based on the description above, the fundamental problem that occurs is the existence of gender inequality experienced by female journalists due to the entrenchment of patriarchal culture in Indonesian society. A comprehensive legal protection strategy is needed to ensure gender equality for female journalists. So, the author is interested in discussing research on "Legal Protection of Female Journalists on Inequality in the Covid-19 Pandemic".

\section{METHOD}

Regarding the type of research used by the author is a type of normative legal research that is a literature analysis based on legal materials used both primary and secondary, discussing doctrines or principles in legal science. ${ }^{6}$ The understanding of normative legal research, according to Philip M. Hadjon, is "research aimed at finding and formulating legal arguments through analysis of the subject." Meanwhile, normative legal research, according to Roni Hanitijo Soemitro, is "research used to examine the rules and principles of law."

This research used the statutory approach and historical approach. The legal approach is carried out by reviewing in more depth the laws and regulations related to the legal protection of female journalists for gender inequality during the Covid-19 pandemic. The historical approach is made by examining the background of what is learned and the development of arrangements on the issues faced. ${ }^{7}$

\section{RESULT AND DISCUSSION}

\section{A. Gender Inequality for Female Journalists during the Covid-19 Pandemic}

The concept of gender is different from sex. The use of gender is to identify the differences between men and women seen from a social and cultural lens. ${ }^{8}$ Gender is interchangeable, while sex is not interchangeable due to God's nature and relates to two biologically determined and attached human sexes. The concept of gender is an inherent trait in both men and

\footnotetext{
${ }^{5}$ Catur Ratna Wulandari, "Pekerja Perempuan di Media Massa Masih Banyak Alami Diskriminasi", Pikiran Rakyat, March 8 2016, accessed from https://www.pikiran-rakyat.com/bandung-raya/pr01251304/pekerja-perempuan-di-media-massa-masih-banyak-alami-diskriminasi.

${ }^{6}$ AZainuddin Ali, “Metode Penelitian Hukum," 2016. p.24.

7 Johnny Ibrahim, Teori dan Metode Penelitian Hukum Normatif, Bayumedia, Malang, 2005, p. 249.

${ }^{8}$ M. Fakih, "Analisis gender dan transformasisosial. Pustaka Pelaajar, Yogyakarta, 2013, p. 7.
} 
women as a result of social and cultural constructs, such as women who are described as meek, emotional, beautiful, motherly, and others. At the same time, men are depicted with strong and rational figures. We need to realize. This concept is not absolute. There are women who are strong and rational, and there are men who are meek and emotional. From the times and classes of society, we can see, in certain times and tribes, there are women stronger than men. So as the times change and according to the place and class of society, the nature of women and men is interchangeable. ${ }^{9}$

The stereotype that women are emotionally personal results in the position of women always in an insignificant part. Stereotypes, according to $\mathrm{KBBI}$, are a conception of the nature of a group based on subjective and inappropriate prejudices. Stereotypes can cause stigma and will certainly cause harm and injustice. For example, stereotypes that look down on women can cause injustice against women. What is faced by female journalists in their roles as a female workforce can be seen from dividing time between taking care of family and completing their work. Social control in work done by women makes men benefit materially from the concept of patriarchal culture. This creates a male profit base from the culture.

There are several things that need to be understood in the context of gender differences, namely: (1) gender injustice and discrimination, this relates to various roles and positions between women and men, both in the form of legal and policy impacts that cause various injustices that are rooted in customs, norms, and structures in society; (2) gender equality and justice, intertwined with status and can have the same conditions without discriminating between men and women, both in the political, social, cultural, and other fields. ${ }^{10}$

The gender perspective in the mass media work environment is an embodiment of critical awareness that the management and media workers are not only well run by men but also women. It can be said that gender awareness is not solely tied to the type of sexuality of the individual. Until now, there are still mass media that place the position of women in the context

\footnotetext{
9 Ni Nyoman Sukerti, I Gusti Ayu Agung Ariani, and I Gusti Agung Ayu Ari Krisnawati, "IMPLIKASI IDEOLOGI GENDER DALAM HUKUM ADAT BALI (STUDI DI KOTA DENPASAR)," Jurnal Magister Hukum Udayana (Udayana Master Law Journal), Volume 5 Number 4, 2016, p. 805-817.

${ }^{10}$ Lampe,"Perempuan dalam pengelolaan surat kabar di Sulawesi Tengah (studi posisi dan peran perempuan dalam media cetak)", Academica-JurnalIlmuSosial dan IlmuPolitikFisipUntad, Volume 02 Number 01, 2010, p. 359-372.
} 
of dichotomy, while men as rivals. ${ }^{11}$ Marginalization and subordination for women in various fields are gender issues that occur in the media, such as the lack of engagement for women in journalism activities, legitimacy about gender bias, regulation of gender insensitive media about gender-dominating economic and political interests, and the gap between conventional and gender-sensitive journalism.

government-owned radio management office in 2016 showed that gender differences associated with media management experienced considerable inequality. This inequality is seen from the number of male employees who are more than the number of female employees, 45 percent of employees are women, and 55 percent are men. Placement of contract status also experienced inequalities that impacted limited career opportunities for women. Even in a structural position; Of the 900 structural positions, women only fill about 300 structural positions. It is also dominant at the administrative level. This condition is slightly higher than the minimum limit or critical mass representation of women in the political sphere. ${ }^{12}$ Not only in Indonesia, the lack of women involved in the management and ownership of the media also occurs in America. Byerly's research showed that less than six percent of women manage and own media such as television and radio stations. ${ }^{13}$

Reporting from Mediaindonesia.com dated April 3, 2021, the SecretaryGeneral of AJI Indonesia - Ika Ningtyas - in a seminar themed "Caring for Freedom of the Press and Freedom of Expression in the midst of Pandemic Repression" at the Secretariat of AJI Tanjungpinang, Saturday (3/4), said, based on the results of a survey the number of cases of violence against female journalists during the Covid-19 pandemic in 2020 was high. Ika also said that violence against female journalists caused a small number of female journalists. The number of AJI activists across Indonesia in 2020 reached 1,800 people and only about 20 percent of women. Based on AJI data, in addition to the violence of female journalists, the number of cases of violence against journalists, both men, and women, is quite high. AJI recorded 84 cases of violence against journalists in 2020. Ika added the Covid-19 pandemic is the highest number of sexual violence against journalists for more than ten years. During the Covid-19 pandemic, violence was experienced by female

${ }^{11}$ Dwi Pusparini dan Gede Made Swardhana, "Urgensi Perlindungan Hukum Terhadap Jurnalis Perempuan Berspektif Kesetaraan Gender", Jurnal Magister Hukum Udayana (Udayana Master Law Journal), Volume 10 Number 01, 2021, p. 187-199.

12 Yolanda Stellarosa dan Martha Warta Silaban, "Perempuan, media dan profesijurnalis", Jurnal Kajian Komunikasi, Volume 7 Number 1, 2019, p. 97-109.

13 Byerly, "Behind the scenes of women's broadcast ownership", Howard Journal of Communication,Volume 22 Number 1, 2011, p. $24-42$. 
journalists, such as physical violence, digital attacks, intimidation, and also the destruction of goods while doing coverage. Data obtained from AJI as many as 58 cases of the perpetrator is an apparatus.. ${ }^{14}$

The Mausia Human Rights perspective should also underlie the world of journalist work that does not distinguish between male and female workers, both of whom have equal job opportunities to get a job and an income. The Human Rights Perspective assumes that human beings are born equal, equal, and have freedom (free and equal). Normatively women and men accept equal rights, but in reality, it has not worked as it should. The rights of female journalists as women are juridically formally guaranteed and regulated by the conditions that are the responsibility of the state to protect women as citizens in order to obtain basic human rights and freedoms. ${ }^{15}$ Therefore, female journalists should get the protection of rights and gender equality, especially during the Covid-19 pandemic. But in reality, there are still many cases of gender injustice experienced by female journalists.

\section{B. Legal Protection of Female Journalists over Gender Inequality}

As stated in article 1 paragraph (3) of the Constitution of the Republic of Indonesia, Indonesia is a state of law. This has the consequence that all staterelated implementation must be in accordance with the law and applicable to all aspects of life so as to create the desired legal purpose. ${ }^{16}$ It needs a strategy related to fostering all forms of support from various parties to create a legal foundation that guarantees freedom for the press. Regulations on the provision of reflection in providing freedom of opinion in Indonesia need to be amended in order to provide more guarantees in terms of press freedom. It will be necessary to expressly prohibit the government from making regulations that can put limits on the freedom of the press itself as well as in terms of independence in opinion. ${ }^{17}$

Judging from the theory of the welfare state initiated by Prof. Mr. R. Kranenburg, that the state must actively strive for welfare, act fairly that can

14 Tanpanama, “AJI: Waspadai Kekerasan terhadap Jurnalis Perempuan”, Media Indonesia, April 3, 2021, accessed from https://mediaindonesia.com/humaniora/395334/aji-waspadai-kekerasanterhadap-jurnalis-perempuan.

${ }^{15}$ Arip Ambulan Panjaitan an charlyna S. Purba, "Tantangan yang Dihadapi Perempuan di Indonesia: Meretas Ketidakadilan Gender", Jurnal Hukum Media Bhakti, 2018, p. 70-95.

${ }^{16} \mathrm{Ni}$ Luh Made DwiPusparini, A ASagung Laksmi Dewi, and I Made Minggu Widyantara, "Urgensi Saksi Pelaku Yang Bekerjasama (Justice Collaborator) Dalam Tindak Pidana Korupsi," Jurnal Interpretasi Hukum, Volume 1 Number 1, 2020, p. 179-185.

17 Malang Harijanto, "PERLINDUNGAN HUKUM TERHADAP WARTAWAN DALAM PELIPUTAN BERITA-BERITA PEMERINTAHAN DAN MASYARAKAT,"Jurnal Hukum Unsrat, Volume 2 Number 1, 2014, p. 1-15. 
be felt by the whole community in an equal and balanced manner, not for the welfare of certain groups but all people. ${ }^{18}$ Thus, female journalists in Indonesia should be able to feel gender equality during the Covid-19 pandemic. Gender equality is a form of welfare that must be accepted by female journalists and must be guaranteed by the state, and there is legal protection.

There needs to be an ideological construct on the role and abilities of every woman. This can have an influence in obtaining opportunities both individually and institutionally. ${ }^{19}$ The government in Indonesia officially adheres to the principle of equality stipulated in article 27 of the Constitution of the Republic of Indonesia of 1945, which states that all Indonesian citizens are domiciled equally before the law so that both men and women are equally positioned and entitled to access and participation in all fields, both social, political, and economical.

On the international scene, there has been a declaration governing women's rights. Article 1 of the universal declaration governing human rights says that everyone is born independent, dignified, has equal rights and is endowed with reason and conscience so as to socialize with others. In addition, article 1 of the Convention on the Elimination of Discrimination against Women gives an understanding of discrimination. The article states that discrimination is exclusion, differences, or restrictions based on gender that greatly affects reducing the use of human rights and freedoms in all fields. Articles of the International Convention on Human Rights that eliminate all forms of discrimination against women include:

a) Condemnation of all forms of discrimination, enforcement efforts regarding women's equal rights and obligations in the Act;

b) Obligations to states in the form of regulations on the elimination of discrimination against women in both politics and community life;

c) The obligation of each country incorporated in the establishment of rules on the elimination of discrimination for women in all activities (education, health, obtaining employment, and socioeconomics);

d) The obligation of each state in terms of the provision of equal rights for women in the face of law and the elimination of discrimination in matters of marriage and in the case of familial relations;

\footnotetext{
18 Soemardi, "Teori Umum Hukum dan Negara: Dasar-Dasar Ilmu Hukum Normatif Sebagai Ilmu Hukum Deskriptif-Empirik", Bee Media Indonesia, Bandung, 2010, p. 225.

${ }_{19}$ Louisa Yesami Krisnalita, "Perempuan, Ham Dan Permasalahannya Di Indonesia," Binamulia Hukum, Volume 7 Number 1, 2018, p. 71-81.
} 
e) Establishment of an international committee in assessing progress on implementation;

f) Each state has the right to make objections.

The International Convention on Elimination of All Forms of Discrimination Against Woman, which has been ratified into Law No. 7 of 1984, has three main principles, among others: ${ }^{20}$

- In terms of substantive equality, which obliges the state to guarantee equality between women and men, either in the form of legislation or otherwise that focuses on access and enjoyment of the same benefits of facilities and infrastructure.

- The principle of non-discrimination, namely in achieving equality between women and men, must eliminate all forms of discrimination.

- The principle of state obligations, namely guaranteeing women's rights through steps in creating conducive conditions for capacity building in obtaining opportunities and opportunities, especially in the public sector.

Based on the explanation above, both international and national law has stated that the laws and regulations recognize the principle of equal rights and obligations between women and men. However, in its implementation in the administration of the law, it still creates injustice. One of the reasons is the patriarchal culture that develops in indigenous peoples in Indonesia, where men are the holders of power, thereby degrading women. ${ }^{21}$ There need to be additional efforts in the form of countermeasures from the community with early learning through law education. The learning aims to educate the next generation of the nation in terms of mutual respect and protection of human rights. Changes in matters related to gender ideology will slowly form a society that understands and upholds gender equality. This will have a considerable influence in all areas of community life. ${ }^{22}$ The legal culture in

${ }^{20}$ Dwi Pusparini dan Gede Made Swardhana, "Urgensi Perlindungan Hukum Terhadap Jurnalis Perempuan Berspektif Kesetaraan Gender", Jurnal Magister Hukum Udayana (Udayana Master Law Journal), Volume 10 Number 01, 2021, p. 187-199.

${ }^{21}$ Dede Kania, "HakAsasi Perempuan Dalam Peraturan Perundang-Undangan Di Indonesia: The Rights of Women in Indonesian Laws and Regulations," Jurnal Konstitusi, Volume 12, Number 4, 2015, p. 716-734.

${ }^{22}$ I Ketut Sudantra and I Gusti Ngurah Dharma Laksana, "PENGARUH IDEOLOGI GENDER TERHADAP PERKEMBANGAN HAK WARIS PEREMPUAN BALI," Jurnal Magister Hukum Udayana (Udayana Master Law Journal), Volume 5 Number 4, 2016, p. 818-832. 
society also needs to increase sensitivity to the issue of sexual violence, especially violence against women.

In addition to law education and increasing sensitivity to the issue of sexual violence in the legal culture of society, there is also a need for ideological deconstruction in countering the degrading influence of women and against assumptions about the absence of women's participation in development to end the system of gender inequality experienced by female journalists. ${ }^{23}$ In addition, legal reconstruction must carry out against actions that degrade the dignity of women journalists. That is a basis for women to fight injustice or discrimination both nationally and internationally.

\section{CONCLUSION}

It is still sporadic for people to raise issues related to gender inequality experienced by female journalists. There are several gender problems in the media. Such as the lack of women's involvement in journalism activities, marginalization and subordination for women in various fields, legitimacy regarding gender bias, dominating economic and political interests, regulations on media that are not sensitive to gender, and the gap between conventional journalism and gender equality. During the Covid-19 pandemic, sexual violence against journalists was the highest in more than ten years. During the Covid-19 pandemic, the violence experienced by female journalists included physical violence, digital attacks, intimidation, and also the destruction of goods while reporting. There need to be additional efforts in countermeasures from the community with early learning through law education. The teaching aims to educate the next generation of the nation regarding mutual respect and protection of human rights. In addition, it is also necessary to reconstruct the law, considering that women have the same position as men in terms of their situation, rights, and obligations so that they have equal opportunities in various fields.

\section{DECLARATION OF CONFLICTING INTERESTS None}

\section{FUNDING INFORMATION}

\section{None}




\section{ACKNOWLEDGEMENT}

This journal cannot be separated from the guidance and encouragement from various parties, so that the author, in particular, would like to thank profusely all those who have helped. On this occasion, the writer would like to express his deepest gratitude to: (1) Allah SWT with all His graces and gifts that give strength to the author in completing this journal; (2) Mrs. Dr. Sang Ayu Putu Rahayu, SH, MH as a lecturer in the Research Methods and Legal Writing course who has provided guidance and direction so that I can complete this journal; (3) The author's father who always provides material and non-material support in writing this journal; (4) Fellow learner: Bayu Bimantara, Muhammad Fauzi, and Muhammad Iqbal Baiquni. Thank you for the motivation and input so that the author can complete this journal; (5) Friends Welcoming the Future: Meidi, Ulfi, Salsa, Tia, and Nessya. Thank you for your motivation and support so that the writing of this journal can be completed quickly; and (6) Survive Forever's friends: Ari, Mike, Meli, Dhani, Azza and Nurus for their motivation and support so the author can finish this journal.

\section{REFERENCES}

Ali, A. Z. (2016). Metode Penelitian Hukum. Jakarta: Kencana.

Anom, E. (2011). Wajah Pers Indonesia 1999-2011. Jurnal Komunikasi: Malaysian Journal of Communication, 27( 1), 101-114.

Anonim.(April 2021). “AJI: Waspadai Kekerasan terhadap Jurnalis Perempuan", Media Indonesia, April 3 2021,accessed from https://mediaindonesia.com/humaniora/395334/aji-waspadai-kekerasanterhadap-jurnalis-perempuan.

Byerly. (2011). Behind the scenes of women's broadcast ownership. Howard Journal of Communication, 22 (1), 24-42.

Fakih, M. (2013). Analisis gender dan transformasi sosial. Yogyakarta: Pustaka Pelajar.

Harijanto, Malang. (2014). PERLINDUNGAN HUKUM TERHADAP WARTAWAN DALAM PELIPUTAN BERITA-BERITA PEMERINTAHAN DAN MASYARAKAT. Jurnal Hukum Unsrat, 2 (1), $1-15$.

Hidajadi, M. (2003). Hubungan Ibu dan Anak Perempuan: Sebuah Distorsi?. Jurnal Perempuan: Untuk Pencerahan dan Kesetaraan, 16, 7-15.

Ibrahim, J. (2005). Teori dan Metode Penelitian Hukum Normatif. Malang: Bayumedia. 
Kania, Dede. (2015). Hak Asasi Perempuan Dalam Peraturan PerundangUndangan $\mathrm{Di}$ Indonesia: The Rights of Women in Indonesian Laws and Regulations. Jurnal Konstitusi, 12 ( 4), 716-34.

Khotimah, Khusnul. (2009). “Diskriminasi Gender Terhadap Perempuan Dalam Sektor Pekerjaan." Yinyang: Jurnal Studi Islam Gender Dan Anak, 4 (1) , 158-80

Krisnalita, L. Y. (2018). Perempuan, Ham Dan Permasalahannya Di Indonesia. Binamulia Hukum, 7 (1), 71-81.

Lampe. (2010). Perempuan dalam pengelolaan surat kabar di Sulawesi Tengah (studi posisi dan peran perempuan dalam media cetak). Academica-Jurnal Ilmu Sosial dan Ilmu Politik Fisip Untad, 02 (01), 359372.

Panjaitan, A. A. (2018). Tantangan yang Dihadapi Perempuan di Indonesia: Meretas Ketidakadilan Gender. Jurnal Hukum Media Bhakti, hlm. 70-95.

Pusparini, D, Gede M. S. (2021). Urgensi Perlindungan Hukum Terhadap Jurnalis Perempuan Berspektif Kesetaraan Gender. Jurnal Magister Hukum Udayana (Udayana Master Law Journal), 10 (01), 187-199.

Pusparini, N. M. L. D., dkk. (2020). Urgensi Saksi Pelaku Yang Bekerjasama (Justice Collaborator) Dalam Tindak Pidana Korupsi. Jurnal Interpretasi Hukum, 1 (1), 179-85.

Ramli, M. A. Analisis Gender Dalam Hukum Islam. Jurnal Figh, 9, hlm. 13762.

Republic of Indonesia. Undang-Undang Dasar Negara Republik Indonesia 1945. Lembaran Negara Republik Indonesia Tahun 2014 Nomor 383, Tambahan Lembaran Negara Republik Indonesia Nomor 5650. Accessed from https://www.bphn.go.id/data/documents/14uu042.pdf.

Republic of Indonesia, Undang-Undang Nomor 40 Tahun 1999 tentang Pers. Lembaran Negara Republik Indonesia Tahun 1999 Nomor 166, Tambahan Lembaran Negara Republik Indonesia Nomor 3887.

Republic of Indonesia, Undang-Undang Nomor 7 Tahun 1984 tentangPengesahan Konvensi Mengenai Penghapusan Segala Bentuk Diskriminasi Terhadap Wanita (Convention On The Elimination Of All Forms Of Discrimination Against Women). Lembaran Negara Republik Indonesia Tahun 1984 Nomor 29, Tambahan Lembaran Negara Republik Indonesia Nomor 3277.

Soemardi. (2010). Teori Umum Hukum dan Negara : Dasar-Dasar Ilmu Hukum Normatif Sebagai Ilmu Hukum Deskriptif-Empirik. Bandung: Bee Media Indonesia.

Stellarosa, Y., Martha W. S. (2019). Perempuan, media dan profesi jurnalis. Jurnal Kajian Komunikasi, 7 (1),97-109. 
Sudantra, I. K., I Gusti Ngurah Dharma Laksana. (2016). PENGARUH IDEOLOGI GENDER TERHADAP PERKEMBANGAN HAK WARIS PEREMPUAN BALI. Jurnal Magister Hukum Udayana (Udayana Master Law Journal), 5 (4), 818-32.

Sukerti, N. N., dkk. (2016). IMPLIKASI IDEOLOGI GENDER DALAM HUKUM ADAT BALI (STUDI DI KOTA DENPASAR). Jurnal Magister Hukum Udayana (Udayana Master Law Journal), 5 ( 4), 805-17.

Untari, P. H. (Mei 2020). “Nasib Jurnalis di Tengah covid-19, Tuntutan Tinggi tapi Minim Perlindungan", Oke News, May 18 2020, accessed from https://nasional.okezone.com/read/2020/05/18/337/2215933/nasibjurnalis-di-tengah-covid-19-tuntutan-tinggi-tapi-minimperlindungan?page $=2$.

Wulandari, C. S. (Maret 2016). “Pekerja Perempuan di Media Massa Masih Banyak Alami Diskriminasi", Pikiran Rakyat, March 8 2016, accessed from https://www.pikiran-rakyat.com/bandung-raya/pr01251304/pekerja- perempuan-di-media-massa-masih-banyak-alamidiskriminasi. 


\section{ABOUT AUTHOR(S)}

Vena Lidya Khairunissa is a student at the Faculty of Law at the State University of Semarang. She completed high school education at SMA Negeri 5 Semarang, then continued her higher education in the Department of Law, Undergraduate Program, Faculty of Law, the State University of Semarang in 2019. In addition, he is active in organizations such as UKM Fiat Justicia UNNES and the Student Publishing and Press Agency ( BP2M) UNNES. In 2019, she became a member of Commission 1 (Advocacy Commission) of Fiat Justicia. In 2021, she was entrusted with being the treasurer of Fiat Justicia Unnes. Meanwhile, at BP2M UNNES in 2021 until now, she has been entrusted with being an Express bulletin reporter and a member of the Company's Leaders. The author is also involved in off-campus activities such as: an internship in Liaison with the Central Java Judicial Commission (2021) and the Legal Bureau of the Semarang City Secretary (2021).

Mochammad Ilham Nurrobby, born in Tuban, East Java on December 31th 1999, is a student of Industrial Management, Lunghwa University of Science and Technology. Participate as a member on Indonesian Student Association of Lunghwa University of Science and Technology or usually called PPI LHU (Perhimpunan Pelajar Indonesia Lunghwa University), has been on 2nd place of highest total score in class in second semester, and got a level 2 certificate of TOCFL on the first year in Taiwan. 